\title{
PERCEPTION OF ONLINE LEARNING BY STUDENTS OF UNIVERSITY PEDAGOGICAL STUDY PROGRAMS DURING COVID-19 PANDEMIC
}

\author{
${ }^{\mathrm{a} P E T R}$ ADAMEC, ${ }^{\mathrm{b}}$ MICHAL ŠIMÁNĚ
}

Mendel University in Brno, Institute of Lifelong Learning, Zemédělská 1665/1, Czech Republic email: ${ }^{a}$ petr.adamec@mendelu.cz, ${ }^{b}$ michal.simane@mendelu.cz

Abstract: The text focuses on the issue of online learning during the COVID-19 pandemic. Specifically, the authors focus on capturing, describing and interpreting the perception of online learning through the online tools MS Teams and LMS Moodle. The paper is based on data obtained from a research survey based on a quantitative approach. A self-designed questionnaire was chosen as the data collection tool. The questionnaire survey was conducted electronically among university students in pedagogical fields in the period from November 2020 to March 2021. In total, the authors analysed data from 462 questionnaires received. Not only the basic descriptive authors analysed data from 462 questionnaires received. Not only the basic descriptive variables were evaluated, using adequate parametric and non-parametric tests.

Keywords: students; perception; vocational education; pedagogical disciplines; questionnaire; COVID-19.

\section{Introduction}

For almost two years now, daily life in many areas of human society has been accompanied by the need to comply with a number of measures to combat the spread of COVID-19. Education and training in this regard is no exception. According to Pokhrel and Chhetri (2021), the spread of the disease is considered the largest disruption of education systems in human history, affecting nearly 1.6 billion primary, secondary and tertiary students in more than 200 countries. In other words, as both authors add, more than $94 \%$ of all pupils and students around the world have been affected by the closure of schools and other educational institutions. In this respect, this new situation can be compared to the great crises of the 20th century, such as the Second World War, the Great Depression or the Spanish flu of 1918-1920 (see, for example, Vargo et al., 2021).

The Czech Republic was one of the countries significantly affected by the COVID-19 pandemic. As in other countries, the government of the Czech Republic was faced with a demanding challenge. As early as March 2020, the government began to take a number of measures, which also affected the field of education and training (see, for example, Komenda et al., 2020). The individual measures taken in this area have thrown both pupils and students of schools and their teachers into a completely new situation. As pointed out, for example, by Pozo et al. (2021), pupils, students and teachers had no choice but to adapt to the situation and to complete and implement the current form of learning by distance learning methods. In particular, teachers essentially were faced from day to day with the task of requiring a quick solution, i.e. to quickly convert their full-time learning into a distance form. And this, as Gillis and Krull (2020) state, often with little or no knowledge and experience of how to actually do so.

\section{Starting points}

In general, the transition to distance learning has posed a number of obstacles for pupils, students and their teachers as a result of the spread of COVID-19. In this connection, we can mention, for example, problems with the availability of study materials, problems with the Internet connection, problems with the acquisition of hardware in the form of PCs, laptops, etc., with which it is possible to connect to the Internet, etc. However, the actors of education also had to solve other problems, such as an understandable preference for caring for a sick person at the expense of implementation or completion of learning, possible health problems, etc. A completely unique aspect of the whole situation was the appeal to pupils COVID-19 to reduce and keep their personal contacts to a minimum. As a result of decisions taken against the spread of COVID-19 by the government of the Czech Republic, often without a clear indication of the end of the restrictions adopted. This interrupted personal contacts both between pupils and students and between pupils, students and their teachers. The closure of educational institutions and selfisolation deprived them of the opportunity to learn together in the classroom, to work together and to participate in the learning that was natural to them until then. At the same time, it led to the creation of an alternative learning environment based mainly on distance learning methods and forms using modern digital technologies (for more see Driessen et al., 2020; Bergdahl \& Nouri, 2021; Pokhrel \& Chhetri, 2021).

Iglesias-Pradas et al. (2021) point out in this connection that, as a result of the pandemic, educational institutions have generally adapted their educational activities in three ways. Namely, by maintaining full-time learning, however, with limited personal contact with both classmates and the teacher. Furthermore, by the creation of a hybrid learning model, i.e. the use of blended learning, which is partly full-time learning in compliance with current anti-epidemiological measures (see note 1 ) and partly distance learning conducted online (for more see also Colpitts, Usick, \& Eaton, 2020; Patricia, 2020; Hrastinski, 2019; Philipsen et al., 2019, etc.). The last way in which educational institutions, not only in the Czech Republic, tried to cope with the limitations of their pedagogical activities, was to transfer learning to a completely online form. However, Iglesias-Pradas et al. (2021), does not mention the fact that, as a result of the measures taken as part of the adaptation characteristics of learning by educational institutions during the COVID-19 pandemic, these institutions used al the methods described above. For example, in the first days of the COVID-19 pandemic in the Czech Republic (Spring 2020), emphasis was put on the social distance of individuals within society, the wearing of respirators, etc. was emphasized (see Komenda et al., 2020). Of course, this was also true in the field of learning, where the hybrid form of education in particular was supported. Another situation prevailed during the closure of educational institutions and during the so-called lockdown, i.e. during the effort to prevent the nationwide movement of persons in order to reduce the possibilities of COVID-19 disease transmission. During the lockdown, of course, educational institutions had to completely switch to online learning. It is necessary to add that even during the period when the schools were open, it was necessary to observe a number of partial measures concerning, for example, the number of pupils or students in the group, wearing respirators, etc. In other words, many schools had to adapt their learning to at least the hybrid form.

It can thus be reasonably assumed that the measures taken by the Czech government to manage schools and other educational institutions required in a relatively short time to equip (or reequip) teachers and classes with adequate technology and decide on the selection of adequate software for online or hybrid education. In other words, to recommend (or order) teachers of schools and other educational institutions to use such software that would facilitate the implementation of education in the new conditions as much as possible. At the same time, the same approached was applied in communication between teachers and their pupils or students, or communication with the parents of these pupils. In this regard, it would be interesting to see which of the various web-based tools and applications supporting online learning pupils, students and teachers preferred in this regard during the COVID-19 pandemic.

Although there has been no such study so far (during the writing of this article, its authors did not encounter any such study) that would shed light on this issue, in this context, the study of Vargo et al. (2021), which focuses on a meta-analysis of professional articles related to the use of digital technologies in education during the COVID-19 pandemic (Spring 2020) can be of some help. The authors claim that teachers and students during the COVID-19 pandemic period (Spring 2020) mainly used videobased devices and platforms (such as Zoom, WebEx, Google hangouts, GitHub, etc.), especially with the aim to replace faceto-face online learning, for mutual communication and for 
communicating instructions for continuous tasks, for communicating instructions for successful completion of a subject in general, etc. It may be surprising in this respect that these are mainly tools supporting synchronous online learning, and we will not find any mention of the use of tools or applications that would support self-study or asynchronous learning (e.g. LMS Moodle, Schoology, partly also MS Teams). It can be assumed that the selection of adequate software or web tools and applications should, as far as possible, eliminate a number of negative consequences of the transition from full-time to distance learning through digital technologies, such as limited access to educational resources such as textbooks, scripts and other miscellaneous study materials. After all, the closure of schools was accompanied, at least in the Czech Republic, by the closure of public and university libraries.

In this regard, the selection of a suitable software for the successful implementation of online learning, moreover, in a situation where a decision had to be made in a very short time, proves to be very critical. This is in view of the unexpected consequences and impacts in many areas of education implementation. And it is precisely some of the consequences and impacts of learning through online tools that our study focuses on. Specifically, on the perception of online learning, its consequences and impacts among university students in pedagogically oriented study programs during the COVID-19 pandemic in the Czech Republic.

We perceive the benefit of our study mainly in capturing the partial situation of the researched issue in the Czech Republic. However, the results of our research can also contribute to a broader professional discussion on this or a similar topic. Our findings follow, for example, other professional quantitative texts, such as the study of Polish authors Baczek et al. (2021), who deal with the same issue, however, focusing on medical students. But also a study by Gillis and Krull (2020) can be mentioned, in which they found out students' attitudes to distance learning during the first wave of COVID-19 (Spring 2020) in the USA. It is also the text of the authors Pal and Vanijja (2020), who conducted research on a similar topic in India and many others that can serve as a good example.

\section{Methodology}

The specific goal of our study was to determine the manner and degree of perception of the course of online learning among university students of pedagogically oriented study programs during the COVID-19 pandemic. Therefore, the main research question for us was the question of how and to what extent university students of pedagogically oriented study programs perceived the course of online learning during the COVID-19 pandemic? We focused on issues related to student activities during online learning, evaluation of the pros and cons of eonline learning compared to "traditional" learning, but also, for example, student satisfaction with the use of various online learning tools, such as MS Teams, or LMS Moodle etc.

The research investigation of this topic is based on a quantitative approach. The data collection tool was a questionnaire. This was constructed by the authors on the basis of a study of professional sources (partly mentioned in this study, eg Bączek et al., 2021) and with regard to our main research question. The questionnaire contained a total of 22 questions. The items of the questionnaire focused on several main areas of perception of the course of online learning by university students. In this study, however, due to the scope of the research survey and the possibilities of the scope of this text, we present only a partial part of the results. The mentioned scope of partial use of the results was also chosen with regard to the relevance and consistency of the content and topic of the whole paper. For simplicity, the selected indicators can be divided into the three areas below according to their common denominator. These areas were then operationalized into the following question areas (marked as Q).
Q-1) The level of skills and technical equipment of students for online education:

a) How would you describe your level of IT skills?

b) Do you always have the necessary technology available to be able to study online?

c) Do you always have the suitable Internet connection available to be able to study?

d) Did you have to buy any IT equipment to be able to participate in online learning?

e) In case you had to buy some IT equipment, what was the cost in CZK?

Q-2) Advantages and disadvantages of online education in connection with student's own activity:

a) To what extent do you perceive the advantages of online education?

b) To what extent do you perceive the disadvantages of online education?

c) To what extend are you active in online learning and in the traditional form of learning?

Q-3) Satisfaction with selected LMS and the degree of their usage by students:

a) To what extent do you use LMS Moodle in your study activities?

b) What importance do you attach to support study materials in LMS Moodle?

c) To what extend are you satisfied with LMS Moodle?

d) To what extend are you satisfied with MS Teams?

The questionnaire survey was conducted electronically during November 2020 to March 2021. It was a period when all universities in the Czech Republic were closed due to the COVID-19 pandemic and the implementation of education had to go online or hybrid. We conducted research among students of all years of full-time and combined forms of bachelor's degree programs focused on learning, which are implemented at the Institute of Lifelong Learning at Mendel University in Brno (ILL) and bachelor's and master's degree programs at the Faculty of Education, Palacky University in Olomouc (UPOL). During the lockdown, students of these study programs used Microsoft Teams (MS Teams) for synchronous learning and the Moodle learning management system (LMS Moodle) for asynchronous learning, which complemented synchronous learning through MS Teams by offering electronic structured support study materials with basic and advanced study programs. materials, interactive links, videos or spoken word and feedback in the form of questions and tests.

In total, we analyzed data from 462 questionnaires received. After evaluating the basic descriptive results based on absolute and relative frequencies or measures of the central tendency, the statistical significance of the relationships between the variables was determined, using adequate parametric and non-parametric tests. In particular, Pearson's chi-square test, Fisher's exact test or t-test for two independent selections were used. The basic statistical features with which the results were measured for individual questions (dependent variables) were gender and form of study (independent variables)

The detailed structure of the respondents is given in the table below. It shows the standard majority of women in the sample, which also corresponds to the reality in the environment of primary and secondary schools. The youngest respondent was 19 years old and the oldest 56 years old. 
Tab. 1: The respondents' structure

\begin{tabular}{|l|l|c|c|}
\hline \multicolumn{2}{|l|}{ Respondents' structure } & $\begin{array}{c}\text { Absolute } \\
\text { frequency }\end{array}$ & $\begin{array}{c}\text { Relative } \\
\text { frequency }\end{array}$ \\
\hline \multirow{2}{*}{$\begin{array}{l}\text { Study } \\
\text { form }\end{array}$} & full-time & 184 & $39,8 \%$ \\
\cline { 2 - 4 } & combined & 278 & $60,2 \%$ \\
\hline \multirow{4}{*}{ Gender } & male & 93 & $20,1 \%$ \\
\cline { 2 - 4 } & female & 369 & $79,9 \%$ \\
\hline \multirow{4}{*}{ Age } & up to 25 & 265 & $57,4 \%$ \\
\cline { 2 - 4 } & 26 to 30 & 64 & $13,9 \%$ \\
\cline { 2 - 4 } & 31 to 35 & 38 & $8,2 \%$ \\
\cline { 2 - 4 } & 36 to 45 & 72 & $15,6 \%$ \\
\cline { 2 - 4 } & 46 and more & 23 & $5,0 \%$ \\
\hline \multirow{3}{*}{$\begin{array}{l}\text { Study } \\
\text { year }\end{array}$} & Bachelor degree & 399 & $86,4 \%$ \\
\cline { 2 - 4 } & Master degree & 63 & $13,6 \%$ \\
\hline Total & & 462 & $100 \%$ \\
\hline
\end{tabular}

Source: Authors' own work.

\section{Main results of the research survey}

The results are divided according to the thematic areas as described in the methodology. The answers to individual questions are processed in the form of absolute and relative frequencies in the form of tables, where they are also sorted by gender and by form of study. Possible statistically significant relationships between dependent and independent variables are marked with gray colour in the tables and described in the text.

4.1 The level of skills and technical equipment of students for online education

Tab. 2: How would you describe your level of IT skills? (Q-1a)

\begin{tabular}{|c|c|c|c|c|c|c|c|}
\hline & & \multicolumn{2}{|c|}{ full-time } & \multicolumn{2}{|c|}{ combined } & \multicolumn{2}{|c|}{ total } \\
\hline \multirow{4}{*}{$\frac{0}{\pi}$} & basic & 1 & $3,8 \%$ & 6 & $9,0 \%$ & 7 & $7,5 \%$ \\
\hline & intermediate & 17 & $65,4 \%$ & 36 & $53,7 \%$ & 53 & $57,0 \%$ \\
\hline & advanced & 8 & $30,8 \%$ & 25 & $37,3 \%$ & 33 & $35,5 \%$ \\
\hline & total & 26 & $100,0 \%$ & 67 & $100,0 \%$ & 93 & $100,0 \%$ \\
\hline \multirow{4}{*}{ 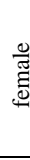 } & basic & 18 & $11,4 \%$ & 21 & $10,0 \%$ & 39 & $10,6 \%$ \\
\hline & intermediate & 122 & $77,2 \%$ & 148 & $70,1 \%$ & 270 & $73,2 \%$ \\
\hline & advanced & 18 & $11,4 \%$ & 42 & $19,9 \%$ & 60 & $16,3 \%$ \\
\hline & total & 158 & $100 \%$ & 211 & $100,0 \%$ & 369 & $100,0 \%$ \\
\hline \multirow{4}{*}{ 퓽 } & basic & 19 & $10,3 \%$ & 27 & $9,7 \%$ & 46 & $10,0 \%$ \\
\hline & intermediate & 139 & $75,5 \%$ & 184 & $66,2 \%$ & 323 & $69,9 \%$ \\
\hline & advanced & 26 & $14,1 \%$ & 67 & $24,1 \%$ & 93 & $20,1 \%$ \\
\hline & total & 184 & $100,0 \%$ & 278 & $100,0 \%$ & 462 & $100,0 \%$ \\
\hline
\end{tabular}

Source: Authors' own work.

Overall, 70\% of respondents rate the level of their IT skills as intermediate. Only a fifth describe it as advanced. It has been shown that the "level of IT skills" differs statistically significantly at the $5 \%$ level of significance $(\mathrm{F}=7,019 ; \mathrm{p}=$ 0,030 ) in terms of form of study and even at the $1 \%$ level of significance $(F=15,465 ; p=0.000)$. Full-time male and students describe their digital skills level as more advanced.

Tab. 3: Do you always have the necessary technology available to be able to study online? (Q-1b)

\begin{tabular}{|c|c|c|c|c|c|c|c|}
\hline & & \multicolumn{2}{|c|}{ full-time } & \multicolumn{2}{|c|}{ combined } & \multicolumn{2}{|c|}{ total } \\
\hline \multirow{3}{*}{ 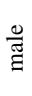 } & yes & 25 & $96,2 \%$ & 58 & $86,6 \%$ & 83 & $89,2 \%$ \\
\hline & no & 1 & $3,8 \%$ & 9 & $13,4 \%$ & 10 & $10,8 \%$ \\
\hline & total & 26 & $100,0 \%$ & 67 & $100,0 \%$ & 93 & $100,0 \%$ \\
\hline \multirow{3}{*}{ 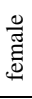 } & yes & 144 & $91,1 \%$ & 185 & $87,7 \%$ & 329 & $89,2 \%$ \\
\hline & no & 14 & $8,9 \%$ & 26 & $12,3 \%$ & 40 & $10,8 \%$ \\
\hline & total & 158 & $100,0 \%$ & 211 & $100,0 \%$ & 369 & $100,0 \%$ \\
\hline \multirow{3}{*}{ 胥 } & yes & 169 & $91,8 \%$ & 243 & $87,4 \%$ & 412 & $89,2 \%$ \\
\hline & no & 15 & $8,2 \%$ & 35 & $12,6 \%$ & 50 & $10,8 \%$ \\
\hline & total & 184 & $100,0 \%$ & 278 & $100,0 \%$ & 462 & $100,0 \%$ \\
\hline
\end{tabular}

Source: Authors' own work.
In general, 9 out of 10 students of learning fields always have the necessary technology available for online education. No statistically significant relationship was found between the variables.

Tab. 4: Do you always have the suitable Internet connection available to be able to study? (Q-1c)

\begin{tabular}{|c|c|c|c|c|c|c|c|}
\hline & & & -time & & bined & & tal \\
\hline \multirow{3}{*}{ 苞 } & yes & 21 & $80,8 \%$ & 56 & $83,6 \%$ & 77 & $82,8 \%$ \\
\hline & no & 5 & $19,2 \%$ & 11 & $16,4 \%$ & 16 & $17,2 \%$ \\
\hline & total & 26 & $100,0 \%$ & 67 & $100,0 \%$ & 93 & $100,0 \%$ \\
\hline \multirow{3}{*}{ 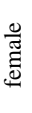 } & yes & 97 & $61,4 \%$ & 161 & $76,3 \%$ & 258 & $69,9 \%$ \\
\hline & no & 61 & $38,6 \%$ & 50 & $23,7 \%$ & 111 & $30,1 \%$ \\
\hline & total & 158 & $100,0 \%$ & 211 & $100,0 \%$ & 369 & $100,0 \%$ \\
\hline \multirow{3}{*}{ 营 } & yes & 118 & $64,1 \%$ & 217 & $78,1 \%$ & 335 & $72,5 \%$ \\
\hline & no & 66 & $35,9 \%$ & 61 & $21,9 \%$ & 127 & $27,5 \%$ \\
\hline & total & 184 & $100,0 \%$ & 278 & $100,0 \%$ & 462 & $100,0 \%$ \\
\hline
\end{tabular}

Source: Authors' own work.

From the above overall results, it can be stated that almost $3 / 4$ respondents have "sufficient internet connection available at all times". It has been proven that the constant possibility of connecting to the Internet differs statistically significantly in terms of gender $(p=0.013)$ and in terms of form of study $(p=$ 0.001 ). Male and male students in the combined form always have sufficient internet connection more than women and students in the full-time form.

Tab. 5: Did you have to buy any IT equipment to be able to participate in online learning? (Q-1d)

\begin{tabular}{|c|c|c|c|c|c|c|c|}
\hline & & & -time & & bined & & btal \\
\hline \multirow{3}{*}{$\begin{array}{l}\stackrel{\mathscr{J}}{\overparen{\Xi}} \\
\end{array}$} & yes & 10 & $38,5 \%$ & 13 & $19,4 \%$ & 23 & $24,7 \%$ \\
\hline & no & 16 & $61,5 \%$ & 54 & $80,6 \%$ & 70 & $75,3 \%$ \\
\hline & total & 26 & $100,0 \%$ & 67 & $100,0 \%$ & 93 & $100,0 \%$ \\
\hline \multirow{3}{*}{ 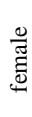 } & yes & 34 & $21,5 \%$ & 39 & $18,5 \%$ & 73 & $19,8 \%$ \\
\hline & no & 124 & $78,5 \%$ & 172 & $81,5 \%$ & 296 & $80,2 \%$ \\
\hline & total & 158 & $100,0 \%$ & 211 & $100,0 \%$ & 369 & $100,0 \%$ \\
\hline \multirow{3}{*}{ ఫేّ } & yes & 44 & $23,9 \%$ & 52 & $18,7 \%$ & 96 & $20,8 \%$ \\
\hline & no & 140 & $76,1 \%$ & 226 & $81,3 \%$ & 366 & $79,2 \%$ \\
\hline & total & 184 & $100,0 \%$ & 278 & $100,0 \%$ & 462 & $100,0 \%$ \\
\hline
\end{tabular}

Source: Authors' own work.

Almost 4/5 of students did not have to purchase any IT equipment due to the introduction of online learning. No statistically significant relationship was found between the variables.

Tab. 6: In case you had to buy some IT equipment, what was the cost in CZK? (Q-1e)

\begin{tabular}{|c|c|c|c|c|c|c|c|}
\hline & & \multicolumn{2}{|c|}{ full-time } & \multicolumn{2}{|c|}{ combined } & \multicolumn{2}{|r|}{ total } \\
\hline \multirow[b]{2}{*}{ O } & up to $5000 \mathrm{CZK}$ & 12 & $46,2 \%$ & 40 & $59,7 \%$ & 52 & $55,9 \%$ \\
\hline & $5001-10000 \mathrm{CZK}$ & 1 & $3,8 \%$ & 9 & $13,4 \%$ & 10 & $10,8 \%$ \\
\hline \multirow{2}{*}{9} & more than $10000 \mathrm{CZK}$ & 13 & $50,0 \%$ & 18 & $26,9 \%$ & 31 & $33,3 \%$ \\
\hline & total & 26 & $100,0 \%$ & 67 & $100,0 \%$ & 93 & $100,0 \%$ \\
\hline \multirow{4}{*}{$\frac{\Omega}{\pi}$} & up to $5000 \mathrm{CZK}$ & 95 & $60,1 \%$ & 136 & $64,5 \%$ & 231 & $62,6 \%$ \\
\hline & $5001-10000 \mathrm{CZK}$ & 22 & $13,9 \%$ & 30 & $14,2 \%$ & 52 & $14,1 \%$ \\
\hline & more than $10000 \mathrm{CZK}$ & 41 & $25,9 \%$ & 45 & $21,3 \%$ & 86 & $23,3 \%$ \\
\hline & total & 158 & $100,0 \%$ & 211 & $100,0 \%$ & 369 & $100,0 \%$ \\
\hline \multirow{4}{*}{ ఫّٓ } & up to $5000 \mathrm{CZK}$ & 107 & $58,2 \%$ & 176 & $63,3 \%$ & 283 & $61,3 \%$ \\
\hline & $5001-10000 \mathrm{CZK}$ & 23 & $12,5 \%$ & 39 & $14,0 \%$ & 62 & $13,4 \%$ \\
\hline & more than $10000 \mathrm{CZK}$ & 54 & $29,3 \%$ & 63 & $22,7 \%$ & 117 & $25,3 \%$ \\
\hline & total & 184 & $100,0 \%$ & 278 & $100,0 \%$ & 462 & $100,0 \%$ \\
\hline
\end{tabular}

Source: Authors' own work. 
One quarter of students had to spend more than CZK 10,000 (approximately EUR 400) to purchase equipment in connection with the transition to online education. However, about threefifths of them incurred costs not exceeding CZK 5,000 (approximately EUR 200). No statistically significant relationship was found between the monitored variables.

\subsection{Advantages and disadvantages of online education in} connection with student's own activity

Students see the possibility of staying at home (72\%) and access to online materials (73\%) as the biggest "advantage of online education". Other attributes are no longer so strongly perceived. It has been shown that students perceive some attributes of the benefits of online education statistically significantly differently, especially in terms of the form of study. These differences were found for the items online access $(P / F=0.000)$, class interactivity $(\mathrm{p}=0.011)$ and comfortable environment $(\mathrm{p}=$ 0.028)

Tab. 7: The advantages of online education (Q-2a)

\begin{tabular}{|l|c|c|c|c|c|c|c|c|c|c|}
\hline & \multicolumn{2}{|c|}{ total } & \multicolumn{2}{c|}{ full-time } & \multicolumn{2}{c|}{ combined } & \multicolumn{2}{|c|}{ male } & \multicolumn{2}{|c|}{ female } \\
\hline & $\mathrm{N}$ & $\%$ & $\mathrm{~N}$ & $\%$ & $\mathrm{~N}$ & $\%$ & $\mathrm{~N}$ & $\%$ & $\mathrm{~N}$ & $\%$ \\
\hline $\begin{array}{l}\text { access to } \\
\text { online } \\
\text { materials }\end{array}$ & 336 & 72,7 & 117 & 63,6 & 219 & 78,8 & 68 & 73,1 & 268 & 72,6 \\
\hline $\begin{array}{l}\text { possibility to } \\
\text { learn when I } \\
\text { want }\end{array}$ & 270 & 58,4 & 106 & 57,6 & 164 & 59,0 & 59 & 63,4 & 211 & 57,2 \\
\hline $\begin{array}{l}\text { possibility of } \\
\text { staying at } \\
\text { home }\end{array}$ & 331 & 71,6 & 124 & 67,4 & 207 & 74,5 & 60 & 64,5 & 271 & 73,4 \\
\hline $\begin{array}{l}\text { class } \\
\text { interactivity }\end{array}$ & 31 & 6,7 & 6 & 3,3 & 25 & 9,0 & 6 & 6,5 & 25 & 6,8 \\
\hline $\begin{array}{l}\text { possibility to } \\
\text { record lectures }\end{array}$ & 212 & 45,9 & 84 & 45,7 & 128 & 46,0 & 42 & 45,2 & 170 & 46,1 \\
\hline $\begin{array}{l}\text { comfortable } \\
\text { environment }\end{array}$ & 278 & 60,2 & 121 & 65,8 & 157 & 56,5 & 51 & 54,8 & 227 & 61,5 \\
\hline
\end{tabular}

Source: Authors' own work.

Respondents identified reduced interaction with a teacher and technical problems as the biggest "disadvantages of online learning". Respondents also saw social isolation and the associated lack of interaction with classmates as a significant disadvantage. The following statistically significant relationships were found between the groups.

Tab. 8: The disadvantages of online education (Q-2b)

\begin{tabular}{|l|c|c|c|c|c|c|c|c|c|c|}
\hline & \multicolumn{2}{|c|}{ total } & \multicolumn{2}{|c|}{ full-time } & \multicolumn{2}{c|}{ combined } & \multicolumn{2}{|c|}{ male } & \multicolumn{2}{c|}{ female } \\
\hline & $\mathrm{N}$ & $\%$ & $\mathrm{~N}$ & $\%$ & $\mathrm{~N}$ & $\%$ & $\mathrm{~N}$ & $\%$ & $\mathrm{~N}$ & $\%$ \\
\hline $\begin{array}{l}\text { reduced interaction } \\
\text { with a teacher }\end{array}$ & 340 & 73,6 & 138 & 75,0 & 202 & 72,7 & 72 & 77,4 & 268 & 72,6 \\
\hline technical problems & 316 & 68,4 & 146 & 79,3 & 170 & 61,2 & 53 & 57,0 & 263 & 71,3 \\
\hline $\begin{array}{l}\text { lack of interaction } \\
\text { with classmates }\end{array}$ & 285 & 61,7 & 118 & 64,1 & 167 & 60,1 & 52 & 55,9 & 233 & 63,1 \\
\hline $\begin{array}{l}\text { worse conditions } \\
\text { for learn. at home }\end{array}$ & 116 & 25,1 & 60 & 32,6 & 56 & 20,1 & 20 & 21,5 & 96 & 26,0 \\
\hline $\begin{array}{l}\text { lack of self- } \\
\text { discipline }\end{array}$ & 239 & 51,7 & 120 & 65,2 & 119 & 42,8 & 41 & 44,1 & 198 & 53,7 \\
\hline social isolation & 299 & 64,7 & 124 & 67,4 & 175 & 62,9 & 52 & 55,9 & 247 & 66,9 \\
\hline
\end{tabular}

Source: Authors' own work.

It has been shown that the significance of some of these disadvantages varies statistically significant with regard to gender and form of study. The female students perceived technical problems $(p=0.006)$ more significantly then male students and social isolation was perceived in the same way ( $\mathrm{p}=$ 0.043). Technical problems were also statistically significantly more negatively perceived by full-time students $(p=0.000)$ as well as worse conditions for learning at home $(p=0.004)$ and lack of self-discipline $(\mathrm{p}=0.000)$.
Chart 1: To what extend are you active in online learning and in the traditional form of learning? (Q-2c)

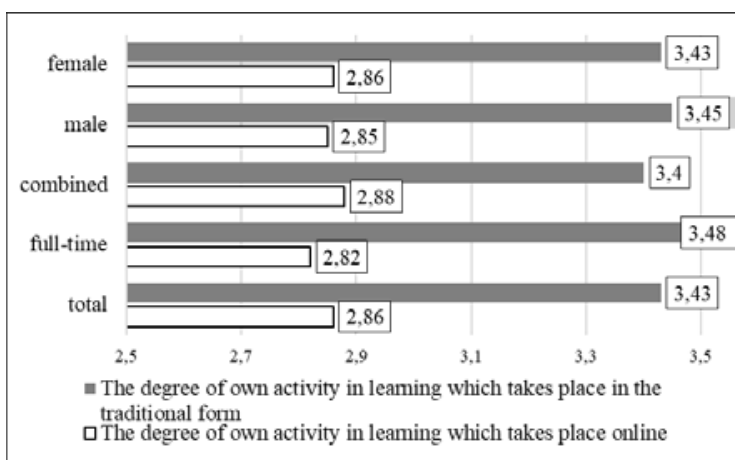

Source: Authors' own work.

In the last question in this question range, the respondents expressed the extent to which they are active in learning that takes place online and in learning that takes place in the traditional way. They answered the question on a scale from 1 to 5 , when the higher the number, the greater the satisfaction. The above chart shows both, the overall average values of responses and the average responses of individual groups. Respondents described themselves as more active in learning, which takes place in the traditional form $(\mathrm{m}=3.43)$ as opposed to the form, which takes place online $(m=2.86)$. No statistically significant relationship was found between the level of activity in the various forms of education and the independent variables in this case. Even the graph itself indicates that the average values of the answers are balanced.

\subsection{Satisfaction with selected LMS and the degree of their} usage by students

Tab. 9: To what extent do you use LMS Moodle in your study activities? (Q-3a)

\begin{tabular}{|c|c|c|c|c|c|c|c|}
\hline & & & -time & & bined & & otal \\
\hline \multirow{5}{*}{$\frac{\mathscr{U}}{\widetilde{\widetilde{G}}}$} & not at all & 10 & $38,5 \%$ & 6 & $9,0 \%$ & 16 & $17,2 \%$ \\
\hline & rarely & 5 & $19,2 \%$ & 26 & $38,8 \%$ & 31 & $33,3 \%$ \\
\hline & occasionally & 8 & $30,8 \%$ & 16 & $23,9 \%$ & 24 & $25,8 \%$ \\
\hline & very often & 3 & $11,5 \%$ & 19 & $28,4 \%$ & 22 & $23,7 \%$ \\
\hline & total & 26 & $100,0 \%$ & 67 & $100,0 \%$ & 93 & $100,0 \%$ \\
\hline & not at all & 31 & $19,6 \%$ & 28 & $13,3 \%$ & 59 & $16,0 \%$ \\
\hline & rarely & 62 & $39,2 \%$ & 39 & $18,5 \%$ & 101 & $27,4 \%$ \\
\hline & occasionally & 50 & $31,6 \%$ & 78 & $37,0 \%$ & 128 & $34,7 \%$ \\
\hline & very often & 15 & $9,5 \%$ & 66 & $31,3 \%$ & 81 & $22,0 \%$ \\
\hline & total & 158 & $100,0 \%$ & 211 & $100,0 \%$ & 369 & $100,0 \%$ \\
\hline \multirow{5}{*}{ 퓽 } & not at all & 41 & $22,3 \%$ & 34 & $12,2 \%$ & 75 & $16,2 \%$ \\
\hline & rarely & 67 & $36,4 \%$ & 65 & $23,4 \%$ & 132 & $28,6 \%$ \\
\hline & occasionally & 58 & $31,5 \%$ & 94 & $33,8 \%$ & 152 & $32,9 \%$ \\
\hline & very often & 18 & $9,8 \%$ & 85 & $30,6 \%$ & 103 & $22,3 \%$ \\
\hline & total & 184 & $100,0 \%$ & 278 & $100,0 \%$ & 462 & $100,0 \%$ \\
\hline
\end{tabular}

Source: Authors' own work.

Less than a quarter of students use LMS "very often," which is not a completely positive finding, but about $1 / 3$ use it "occasionally." Only $16 \%$ of students do not use LMS at all. It was proved that there is a statistically very significant relationship between the rate of use of LMS Moodle in terms of form of study $(\mathrm{F}=36.946 ; \mathrm{p}=0.000)$, where students of combined form use LMS Moodle statistically significantly more often than full-time students. In terms of gender, no significant relationship was found with the use of LMS Moodle. 
Tab. 10: What importance do you attach to support study materials in LMS Moodle? (Q-3b)

\begin{tabular}{|c|c|c|c|c|c|c|c|}
\hline & & & -time & & nbined & & tal \\
\hline \multirow{4}{*}{$\stackrel{\mathscr{U}}{\widetilde{\Xi}}$} & unnecessary & 5 & $19,2 \%$ & 4 & $6,0 \%$ & 9 & $9,7 \%$ \\
\hline & $\begin{array}{l}\text { occasionally } \\
\text { useful } \\
\end{array}$ & 16 & $61,5 \%$ & 33 & $49,3 \%$ & 49 & $52,7 \%$ \\
\hline & very useful & 5 & $19,2 \%$ & 30 & $44,8 \%$ & 35 & $37,6 \%$ \\
\hline & total & 26 & $100,0 \%$ & 67 & $100,0 \%$ & 93 & $100,0 \%$ \\
\hline \multirow{4}{*}{  } & unnecessary & 23 & $14,6 \%$ & 15 & $7,1 \%$ & 38 & $10,3 \%$ \\
\hline & $\begin{array}{l}\text { occasionally } \\
\text { useful } \\
\end{array}$ & 99 & $62,7 \%$ & 88 & $41,7 \%$ & 187 & $50,7 \%$ \\
\hline & very useful & 36 & $22,8 \%$ & 108 & $51,2 \%$ & 144 & $39,0 \%$ \\
\hline & total & 158 & $100,0 \%$ & 211 & $100,0 \%$ & 369 & $100,0 \%$ \\
\hline \multirow{4}{*}{ 퓽 } & unnecessary & 28 & $15,2 \%$ & 19 & $6,8 \%$ & 47 & $10,2 \%$ \\
\hline & $\begin{array}{l}\text { occasionally } \\
\text { useful } \\
\end{array}$ & 115 & $62,5 \%$ & 121 & $43,5 \%$ & 236 & $51,1 \%$ \\
\hline & very useful & 41 & $22,3 \%$ & 138 & $49,6 \%$ & 179 & $38,7 \%$ \\
\hline & total & 184 & $100,0 \%$ & 278 & $100,0 \%$ & 462 & $100,0 \%$ \\
\hline
\end{tabular}

Source: Authors' own work.

Almost two-fifths of respondents consider the study support materials in LMS Moodle to be "very useful" (38.7\%) and the other half (51.1\%) to be "occasionally useful". Only a tenth of respondents consider them "unnecessary" (10.2\%). No statistically significant relationship or difference was found in the opinion on study aids in LMS Moodle in terms of monitored variables.

Tab. 11: (The level of) satisfaction with LMS Moodle (Q-3c)

\begin{tabular}{|c|c|c|c|c|c|c|c|}
\hline & & \multicolumn{2}{|c|}{ full-time } & \multicolumn{2}{|c|}{ combined } & \multicolumn{2}{|r|}{ total } \\
\hline \multirow{6}{*}{ 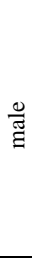 } & great dissatisfaction & 1 & $3,8 \%$ & 3 & $4,5 \%$ & 4 & $4,3 \%$ \\
\hline & dissatisfaction & 5 & $19,2 \%$ & 6 & $9,0 \%$ & 11 & $11,8 \%$ \\
\hline & $\begin{array}{l}\text { neither satisfaction nor } \\
\text { dissatisfaction }\end{array}$ & 11 & $42,3 \%$ & 24 & $35,8 \%$ & 35 & $37,6 \%$ \\
\hline & satisfaction & 6 & $23,1 \%$ & 23 & $34,3 \%$ & 29 & $31,2 \%$ \\
\hline & great satisfaction & 3 & $11,5 \%$ & 11 & $16,4 \%$ & 14 & $15,1 \%$ \\
\hline & total & 26 & $100,0 \%$ & 67 & $100,0 \%$ & 93 & $100,0 \%$ \\
\hline \multirow{6}{*}{ 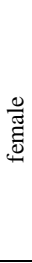 } & great dissatisfac & 8 & $5,1 \%$ & 12 & $5,7 \%$ & 20 & $5,4 \%$ \\
\hline & dissatisfaction & 15 & $9,5 \%$ & 15 & $7,1 \%$ & 30 & $8,1 \%$ \\
\hline & $\begin{array}{l}\text { neither satisfaction nor } \\
\text { dissatisfaction }\end{array}$ & 79 & $50,0 \%$ & 66 & $31,3 \%$ & 145 & $39,3 \%$ \\
\hline & satisfaction & 50 & $31,6 \%$ & 77 & $36,5 \%$ & 127 & $34,4 \%$ \\
\hline & great satisfaction & 6 & $3,8 \%$ & 41 & $19,4 \%$ & 47 & $12,7 \%$ \\
\hline & total & 158 & $100,0 \%$ & 211 & $100,0 \%$ & 369 & $100,0 \%$ \\
\hline \multirow{6}{*}{ 즁 } & great dissatisfaction (1) & 9 & $4,9 \%$ & 15 & $5,4 \%$ & 24 & $5,2 \%$ \\
\hline & dissatisfaction (2) & 20 & $10,9 \%$ & 21 & $7,6 \%$ & 41 & $8,9 \%$ \\
\hline & $\begin{array}{l}\text { neither satisfaction nor } \\
\text { dissatisfaction (3) }\end{array}$ & 90 & $48,9 \%$ & 90 & $32,4 \%$ & 180 & $39,0 \%$ \\
\hline & satisfaction (4) & 56 & $30,4 \%$ & 100 & $36,0 \%$ & 156 & $33,8 \%$ \\
\hline & great satisfaction (5) & 9 & $4,9 \%$ & 52 & $18,7 \%$ & 61 & $13,2 \%$ \\
\hline & total & 184 & $100,0 \%$ & 278 & $100,0 \%$ & 462 & $100,0 \%$ \\
\hline
\end{tabular}

Source: Authors' own work.

Almost two-fifths of respondents expressed a neutral position on the issue of satisfaction with LMS Moodle. However, if we compare the two poles of possible answers and add up their extreme values (great dissatisfaction and satisfaction), then we can state almost half the satisfaction with this product (47\%). At the same time, it was proved that "dissatisfaction" with LMS Moodle" differs statistically significantly in terms of the form of study. Students in the combined form $(\mathrm{N}=278$; $\mathrm{m}=3.55)$ are on average statistically significantly more satisfied $(\mathrm{t}=-3.792 ; \mathrm{df}=$ $460 ; \mathrm{p}=0.000)$ than full-time students $(\mathrm{N}=184 ; \mathrm{m}=3.20)$.
Tab. 12: (The level of) satisfaction with MS Teams (Q-3d)

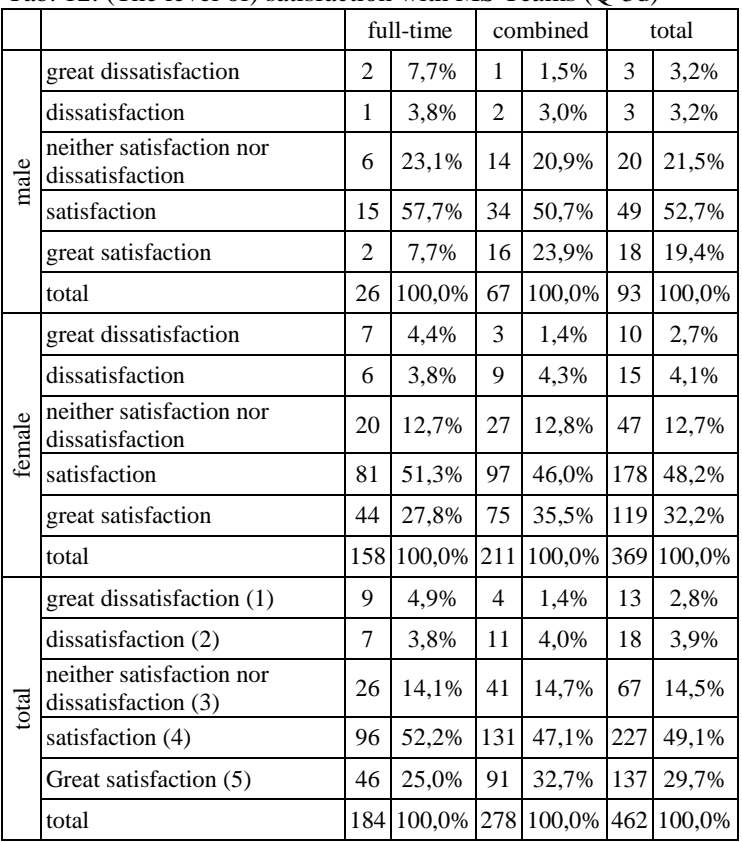

Source: Authors' own work.

Unlike the previous question, the answers focused on satisfaction with MS Teams already more clearly expressed satisfaction with this tool for online education. However, even here it was proved that "dissatisfaction with MS Teams" differs statistically significantly in terms of gender and form of study. Students in the combined form $(\mathrm{N}=278$; $\mathrm{m}=4.06)$ were on average statistically significantly more satisfied $(\mathrm{t}=-1.963$; $\mathrm{df}=$ 460; $\mathrm{p}=0.05$ ) than their colleagues in the full-time form of study $(\mathrm{N}=184 ; \mathrm{m}=3.89)$. At the same time, women $(\mathrm{N}=369$; $\mathrm{m}=4.03)$ were satisfied statistically significantly more $(\mathrm{t}=$ 2.017; $\mathrm{df}=460 ; \mathrm{p}=0.044)$ than men $(\mathrm{N}=93 ; \mathrm{m}=3.82)$.

Chart 2: The level of satisfaction with usage of selected LMS during study (comparison of average values)

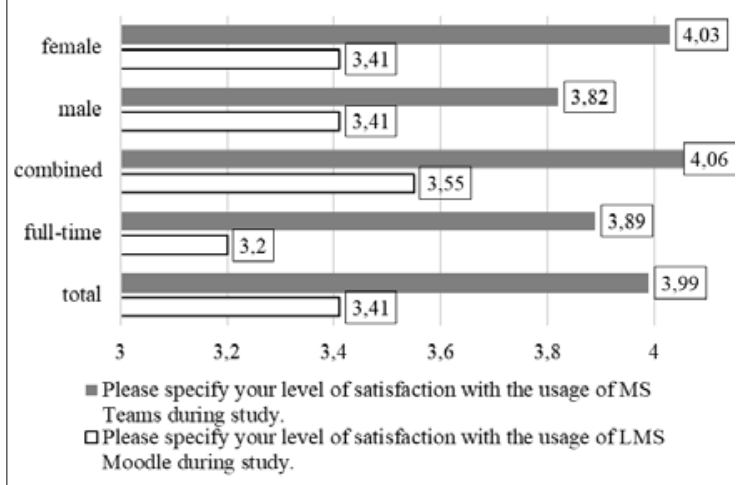

Source: Authors' own work.

\section{Discussion}

Our research survey revealed relatively interesting results, which may be, among other things, a certain stimulus for further implementation of education in online or hybrid form. The obtained data informs about the attitudes of students of teaching disciplines to various aspects of online education. The results certainly show that there are also statistically significant differences (in many cases even at the $1 \%$ level of significance). This is between the attitudes of men and women in relation to some aspects of education during the COVID-19 pandemic. Similarly, it is possible discuss students' attitudes in full-time and combined form of study. If we consider the form of study, we cannot ignore certain age differences, which usually characterize these two traditional forms of university study in the 
Czech Republic and which probably intervened in the results to a certain extent latently.

A closer look at some of the main results reveals, for example, certain problems of students with the availability of the necessary IT equipment and Internet connection. As many authors point out (eg Driessen et al., 2020; Bergdahl \& Nouri, 2021; Pokhrel \& Chhetri, 2021 et seq.), this was a common problem during a pandemic. In a way, however, it revealed the so-called digital divide (see, for example, van Dijk, 2020; Lopez-Sintaz, Lamberti, \& Sukphan, 2020; DiMaggio et al, 2004, etc.), which existed among students in this regard and which was necessary to "bury" and overcome. It should be added that the students needed to do so by themselves, because at the time of this survey there was no government program that would support the purchase of the necessary IT equipment or the possibility of connecting to the Internet from university students. Support for ILL and UPOL in this regard was also minimal. After all, as our survey shows, almost $25 \%$ of students had to spend more than CZK 10,000 (approximately EUR 400) to purchase the necessary equipment due to the ordered introduction of online teaching. Another more than $60 \%$ of students invested up to CZK 5,000 (approx. 200 EUR) in the purchase of equipment due to participation in online lessons. At the same time, it can be assumed that it was a relatively high and unexpected expense, especially for full-time students, which could have caused further barriers in their studies.

Based on our results, a similar situation can be observed in connection with the Internet connection, when almost 30\% of respondents stated that they did not have a sufficient Internet connection, which could limit their course of education to some extent. In this context, it is interesting to note that men and general students in the combined form of study always have sufficient Internet connection more than women and generally full-time students.

Furthermore, the findings of our research are already somewhat more positive with regard to the implementation of online learning from the perspective of students. In this regard, the respondents positively assessed the synchronous part of online learning, which took place through the MS Teams application. Almost $80 \%$ of all respondents were very satisfied or satisfied with the use of this tool during online learning. It may be a surprise to find that "dissatisfaction with MS Teams" differs statistically significantly in terms of gender and form of study. Students in the combined form were more satisfied than their colleagues in the full-time form of study. At the same time, women were more satisfied with this environment than men. We can capture the exact same situation when looking at satisfaction with the LMS Moodle, which was used for the asynchronous part of online learning during the implementation of education during the COVID-19 pandemic. Here, too, students in the combined form were more satisfied than their colleagues in the full-time form of study. At the same time, women were more satisfied with this environment than men.

Another interesting finding was, for example, the fact that satisfaction with LMS Moodle was far lower compared to MS Teams. In particular, only $47 \%$ of respondents stated that they were very satisfied or satisfied with this environment that supports asynchronous learning. A large part (39\%) of respondents were unsatisfied in this respect, i.e. neither satisfied nor dissatisfied. This result partly corresponds to another result of our research that the study support materials in LMS Moodle were used for their studies "very often" by less than a quarter of respondents and as many as $16 \%$ of respondents "at all".

This finding is somewhat surprising because, as reported by Bączek et al. (2021), or Gillis and Krull (2020) LMS Moodle allows, for example, relatively easy access to study materials in electronic form. Similarly, for example, Martín-Blas and Serrano-Fernández (2009) concluded in their research with physics students that students welcome the opportunity to use LMS Moodle. Especially because this environment is generally friendly for them. In other words, through it and in a relatively simple form, they can obtain a large amount of study resources and mainly those resources that the educators usually cannot show them during their learning, usually at the same time, which times of the COVID-19 pandemic due to the closure of university and public libraries were less accessible. Therefore, it could be expected that the use of LMS Moodle, or access to study support materials, will be higher. In this connection, the quality of the processing of study support resources and, in general, their usefulness from the students' point of view may also play a role. Here, data from our research shows that almost $40 \%$ of respondents rate them as very useful and only $10 \%$ of respondents consider them completely useless/unnecessary.

Last but not least, it was interesting to observe what advantages and disadvantages students generally perceived in online education during the COVID-19 pandemic (both synchronous and asynchronous). The results of our survey show that the students perceived as the most significant advantage the opportunity to stay at home (72\%). Other attributes (learning when I want; the ability to record lectures; comfortable environment, etc.) were no longer so strongly perceived. However, it is worth taking a closer look at the "learn when I want" option, which almost $60 \%$ of respondents chose. It is impossible not to recall some ideas in this regard from Prensky (2001), Tapscott (1999) or Makimato and Manners (1997), who at the turn of the millennium drew attention to the arrival of a new generation for whom the use of digital technologies will be a completely natural part of life. The emphasis on learning "online when and where I want" can therefore be a concrete example of both the digital native and the nomad in the field of education, and thus confirming the ideas of these authors and the general popularity of digital technologies among students.

The absence of interaction in the classroom with the teacher proved to be a relatively fundamental problem in the implementation of online learning in our research sample. This is a completely predominant disadvantage, which the respondents selected in the research survey (almost 75\%). Furthermore, during the online form of education, students also had a negative perception of insufficient interaction with classmates (62\%), as well as technical problems in the implementation of learning $(68 \%)$ or social isolation in general $(65 \%)$. In this light, our results seem to mimic the results of other previously conducted research (see, e.g., Baczek, et al., 2021; Erichsen et al., 2014, etc.). As in our research, the prevailing finding in these research studies was that fact that students perceived very negatively during the implementation of online education especially the poor interaction with teachers and classmates, lack of personal contacts (face-to-face), but also, for example, longer duration of answers to questions sent to the teachers, generally poorer communication, lack of motivation leading to procrastination, etc.

\section{Conclusion}

In general, it can be stated that university students of pedagogically oriented study programs provided by ILL and UPOL during the COVID-19 pandemic perceived positively especially the synchronous part of online learning; specifically, working with the MS Teams application, which replaced personal learning, i.e. face-to-face. They were less satisfied with the asynchronous form of learning, i.e. with LMS Moodle, which made available a number of study materials in electronic form within online learning, which were less accessible at the time of the closure of universities and libraries in the Czech Republic. And it is the asynchronous form of online learning (not only LMS Moodle) that is proving to be one of the other research challenges that raises a number of questions that our survey could not answer. Specifically, for example, what are students' ideas about the form of electronic study support materials, their usefulness, general use of asynchronous forms of learning, etc. As some results of our survey show, in addition to these questions it would be appropriate to pay more detailed attention to questions regarding both full - time and combined study form. In a similar way, the issue of quality student connection to the Internet. Although our research was not primarily focused on these phenomena, some of our results show 
that the so-called digital divide can also exist among university students. This opens up space, for example, for the question of whether, to what extent and in what way the ordered transition to online learning has in a relatively short time favoured or disadvantaged university students. Whether the transition from face-to-face learning to a purely online form for some of them did not result in a complete end to the study.

\section{Literature:}

1. Baczek, M., Zagańczyk-Bączek, M., Szpringer, M., Jaroszyński, A., \& Wożakowska-Kapłon, B. (2021). Students' perception of online learning during the COVID-19 pandemic: a survey study of Polish medical students. Medicine, 100(7), e24821. DOI: 10.1097/MD.0000000000024821.

2. Beatty, B., \& Ulasewicz, C. (2006). Online teaching and learning in transition: Faculty perspectives on moving from blackboard to the Moodle learning management system. TechTrends, 50(4), 36-45.

3. Bergdahl, N., \& Nouri, J. (2021). Govid 19 and Crisis Prompted Distance Education in Sweden. Technology, Knowledge and Learning, 26, 443-459.

4. Berge, Z. L., \& Collins, M. (Eds.). (1995). Computermediated communication and the online classroom. New Jersey: Hampton Press.

5. Cohen, A. (2006). Instructional technology and distance learning through the internet. Educational media international, 36(3), 218-229. DOI: 10.1080/0952398990360308.

6. Colpitts, D. F. B., Usick, L. B., \& Eaton, S. E. (2020). Doctoral student reflections of blended learning before and during covid-19. Journal of Contemporary Education Theory \& Research, 4(2), 3-11.

7. DiMaggio, P., Hargittai, E., Celeste, C., \& Shafer, S. (2004). Digital inequality: From unequal access to differentiated use. In K. M. Neckermann (Ed.), Social inequality (pp. 335-400). New York: Russel Sage Foundation.

8. Driessen, E., Beatty, A., Stokes, A., Wood, S., \& Ballen, C. (2020). Learning principles of evolution during a crisis: An exploratory analysis of student barriers one week and one month into the COVID-19 pandemic. Ecology and Evolution, 10, 12431-12436. DOI: https://doi.org/10.1002/ece3.6741.

9. Erichsen, E. A., Bollier, D. U., \& Halupa, C. (2014). Student satisfaction with graduate supervision in doctoral programs primarily delivered in distance education settings. Studies in Higher Education, 39(2), 321-338. DOI: http://dx.doi.org/ 10.1080/03075079.2012.709496.

10. Gillis, A., \& Krull, L. M. (2020). COVID-19 Remote Learning Transition in Spring 2020: Class Structures, Student Perceptions, and Inequality in College Courses. Teaching Sociology, 48(4), 283-299.

11. Hrastinski, S. (2019). What Do We Mean by Blended Learning?. TechTrends, 63, 564-569. DOI: https://doi.org/ 10.1007/s11528-019-00375-5.

12. Iglesias-Pradas, S., Hernández-García, Á., Chapparo-Peláez, J., \& Prieto, J. L. (2021). Emergency remote teaching and students' academic performance in higher education during the COVID-19 pandemic: A case study. Computers in Human Behavior, 119.

13. Komenda, M., Bulhart, V., Karolyi, M., Jarkovský, J., Mužík, J., Májek, O., Šnajdrová, L., Rủžičková, P., Rážová, J., Prymula, R., Macková, B., Březovský, P., Marounek J., Černý V., \& Dušek L. (2020). Complex Reporting of the COVID-19 14. Epidemic in the Czech Republic: Use of an Interactive WebBased App in Practice. Journal of Medical Internet Research, 22(5), e19367. DOI:10.2196/19367.

15. Lopez-Sintas, J., Lamberti, G., \& Sukphan, J. (2020). The social structuring of the digital gap in a developing country. The impact of computer and internet access opportunities on internet use in Thailand. Technology in Society, 63, 101433. DOI: 10.1016/j.techsoc.2020.101.

16. Makimoto, T., \& Manners, D. (1997). Digital nomad. New York: Wiley.

17. Martín-Blas, T., \& Serrano-Fernández, A. (2009). The role of new technologies in the learning process: Moodle as a teaching tool in Physics. Computers \& Education. 52(1), 35-44. https://doi.org/10.1016/j.compedu.2008.06.005.
18. Pal, D., \& Vanijja, V. (2020). Perceived Usability Evaluation of Microsoft Teams as an Online Learning Platform During COVID-19 using System Usability Scale and Technology Acceptance Model in India. Children and Youth Services Review, 110, n. p. DOI: https://doi.org/10.1016/j.childyouth. 2020.105535.

19. Patricia, A. (2020). College Students' Use and Acceptance of Emergency Online Learning Due to COVID-19. International Journal of Educational Research Open, 1, n. p. DOI: https://doi.org/10.1016/j.ijedro.2020.100011.

20. Philipsen, B., Tondeur, J., Pareja Roblin, N. et al. (2019). Improving teacher professional development for online and blended learning: a systematic meta-aggregative review. Education Technology Research and Development, 67, 11451174. DOI: https://doi.org/10.1007.

21. Pokhrel, S., \& Chhetri, R. (2021). A Literature Review on Impact of COVID-19 Pandemic on Teaching and Learning. Higher Education for the Future, 8(1) 133-141.

22. Pozo, J. I., Pérez Echeverría, M. P., Cabellos, B., \& Sánchez, D. L. (2021). Teaching and Learning in Times of COVID-19: Uses of Digital Technologies During School Lockdowns. Frontiers in psychology, 12, 656776. DOI: https://doi.org/ 10.3389/fpsyg.2021.656776.

23. Prensky, M., 2001. Digital Natives, Digital Immigrants Part 1. On the Horizon, 9(5), 1-6. https://doi.org/10.1108/ 10748120110424816.

24. Simonson, M., Smaldino, S., Albright, M., \& Zvacek, S. (2000). Teaching and Learning at a Distance: Foundations of Distance Education. New Jersey: Merrill.

25. Spitzer, M. (2020). Masked education? The benefits and burdens of wearing face masks in schools during the current Corona pandemic. Trends in Neuroscience and Education, 20, 100138. DOI: https://doi.org/10.1016/j.tine.2020.100138.

26. Tapscott, D. (1999). Growing Up Digital: The Rise of the Net Generation. New York: McGraw-Hill.

27. van Dijk, J. (2020). Digital Divide. Cambridge: Polity Press. 28. Vargo D., Zhu L., Benwell B., \& Yan Z. (2021). Digital technology use during COVID-19 pandemic: A rapid review. Human Behavior \& Emerging Technologies, 3, 13-24. DOI: https://doi.org/10.1002/hbe2.24224.

\section{Primary Paper Section: A}

Secondary Paper Section: AM 